\title{
The study of Tai'erzhuang film and TV play
}

\author{
YAN Fen \\ Zaozhuang University, Zaozhuang City, Shandong Province,China \\ super_zhf@163.com
}

Keywords: Film and TV play, The anti-Japanese War, National culture, History writing, Internationalization.

Abstract. This paper makes a systematic analysis of the film and TV plays in Tai'erzhuang, sums up its development and the evolution of artistic style, points out the achievements and shortcomings of the existing papers, discusses the elements as well as the possibility and the art strategy of Tai'erzhuang to be a war blockbuster. This paper is expected to have a guiding significance for the creator of Tai'erzhuang's film and TV plays

\section{Introduction}

The battle of Tai'erzhuang lasted more than one month, and finally achieved a major victory since the anti-Japanese War with the cost of more than 50,000 people died. According to the reports, this battle "wiped out 20,000,000 people, and captured more than 10,000 rifles, 931 heavy machine guns, 77 infantry guns, 40 chariots, 50 artilleries. The Japanese records, the 5 th and12th divisions were killed 2,369 people, injured 9,615 people, a total of more than 12,000 casualties. In addition to the number of casualties after the battle of Xuzhou, 8,000 people were killed in Tai'erzhuang."

The victory of Tai'erzhuang has an important influence both at home and abroad, It becomes the main content of activities like "words, orally, singing, arts, drama, film, parade, etc." The public show of the documentary named "The 400 Million" in the United States and France also changed the international view on the future of China which makes the focus of the World War II shifted from Europe to Asia. Tai'erzhuang also becomes a symbol of the national revival as soon as possible.

\section{The change from the elements of film and TV plays to the theme of them}

During the anti-Japanese period, a large number of patriots and international friends called the peoples to unite together to against Japanese by photographing films of anti-Japanese war. And the great victory of Tai'erzhuang naturally became the favorite elements of creators.

The battle of Tai'erzhuang as film elements first appeared in the documentary named "The 400 Million" which was finished in year 1939, created by Uris Evans, a Holland director. This film is a true record of the Tai'erzhuang battle and plays a great role in publicizing the image of the Chinese nation and showing the national spirit. The film became an important material for the later Chinese anti-Japanese war films; however, due to lots of restrictions, the scene of Tai'erzhuang was not fully portrayed in this movie.

1n 1947, the scene of Tai'erzhuang was also presented in the film "8000 Li of Cloud and Moon" directed by SHI Dongshan. The film tells about a college girl Ling-yu with a party of students propagate anti-Japanese along the iron line, when the battle of Tai'erzhuang is about to break out, they consoled the performance and encouraged the morale of the generals. The film shows the living conditions of the people in the early stage of the battle of Tai'erzhuang, and the scene of the people's efforts to carry out the anti-Japanese war after the outbreak of it.

The battle of Tai'erzhuang, as a theme of film and TV plays, was first appeared in 1980s. At that time, coincided with the reform and opening up, the whole nation launched a cultural reflection movement to emancipate the mind and seek truth from facts. At the same time, Li Zong-ren, the former chairman of Kuomintang, returned to the mainland, and the relationship between the 
Kuomintang and Communist Party began to ease. In this environment, the epic-"The Bloody Battle of Tai'erzhuang" directed by Yang Yuan-guang and Zhai Jun-jie came into being; this is also the first film and TV play in Tai'erzhuang. The film abandons the political position and shows a sense of responsibility and mission from the point of view of national and national survival. For the first time, the film not only made a positive description of Chiang Kai-shek, but also shaped the Kuomintang generals such as Sun Lian-zhong, Chi Feng-cheng and Wang Ming-zhang, and also depicted some moving stories of Kuomintang, the Communist Party, the army and the people, fighting together against Japan. At the same time, the film played a positive role in cross-strait cultural exchanges. Chiang Ching-kuo said:" from this movie, the mainland has admitted that we have been resisting the war. This movie has not blackened my father. It seems that the policy of the mainland (to Taiwan) has been adjusted, and we should make some adjustments accordingly." "The Bloody Battle of Tai'erzhuang" broke the compatriots on both sides of the "silos" barriers. Soon after, Chiang Ching-kuo agreed to the Kuomintang antiwar veterans to go back to the mainland to visit their relatives, and the relations between the two sides of the Straits gradually eased.

"The Bloody Battle of Tai'erzhuang" has played an important role that cannot be ignored in the development of film and TV plays in Tai'erzhuang. It not only tells people that it is possible and valuable to shoot a film in Tai'erzhuang also opens the door of creation as a theme in film and TV plays. This film has also become a classic. If Tai'erzhuang exists as a film element in the "The 400 Million", then it ups to the subject position in "The Bloody Battle of Tai'erzhuang".

\section{A tentative plan for the construction of film and TV plays on the subject of Tai'erzhuang}

At present, the rapid development of Chinese film and TV industry led to the emergence of a series of anti-Japanese film and TV plays. A variety of new works like the TV plays "My Battalion", "Tai'erzhuang History", etc., large historical documentaries "War", "Tai'erzhuang 1938", "The Fight of Tai'erzhuang", "Victory: 70th anniversary sacrifices to the battle of Tai'erzhuang" etc. have been born. Compared with before, today's film and TV plays have a great breakthrough in the narrative strategy. Its international perspective, the combination of official and civilian, the integration of seriousness and entertainment, etc., are well adapted to the current market, have achieved a good response at home and abroad. But there is still no hot film on the theme of Tai'erzhuang on the screen.

In recent years, the emergency of film and TV plays of anti-Japanese war like: "City of Life and Death", "The Hundred Regiments Offensive", "Death and Glory in Changde", "Railway Guerrilla", etc. have become a landscape of the screen culture. But in the narrative, they still pay too much attention to the national theme, little to the inner feelings of individual in the war. In view of the long development, it is a must to change the theme from the integration of the personal and the country to the destruction of human nature by war. This is also an effective way to spread the great spirit of Chinese nation and the national image. Tai'erzhuang film and TV plays are no exception.

\subsection{Compared with other film and TV plays, the construction of Tai'erzhuang blockbusters has a unique advantage}

\subsubsection{A battle for the city}

To some extent, the battle of Tai'erzhuang has many similarities with the battle of Stalingrad. They are both battles that fight around a city. So far, 5 films related to Stalingrad have been filmed, and 2 of them are released globally with good box office and the public praise. But, now, there is only 1 film about Tai'erzhuang which is shown at home.

\subsubsection{A tragic war}

In the war, the bustling canal town of Tai'erzhuang was destroyed in a flash; the size of the forces invested by both sides is rare in the Asian battlefield, "Chinese army input 290 thousands, the Japanese of 50 thousands, Chinese casualties about more than 50 thousands and the Japanese 20 thousands". In the book <Tai'erzhuang>, Fan Chang-jing use "burst of land" to describe this war, 
"South Street lay in disastrous state, the north of it is full of corpses and blood..."1. Therefore, the bloody level of this battle is no less than any other of the Chinese battlefield. The bloody level of the battle is one of the most important elements of the epic temperament of the film, which is beneficial to the artistic reproduction and expression of the creators.

\subsubsection{A victorious war}

Compared with other anti-Japanese war themes, the subject of Tai'erzhuang is more presenting the inspiration of the national spirit. Under the new circumstances, this is undoubtedly of great help to unite national strength, publicize the national image and highlight the core value of China. It can also well show the image of China and the national self-confidence. The victory of the battle of Tai'erzhuang has a historic turning point. It is not only to the world that war does not make Chinese knees also spread the positive image of China and national spirit to the international community, the most important is that the battle of Tai'erzhuang is a few victorious battles, from the point of view, the battle is of creative value.

\subsection{The narrative strategy}

The development of Tai'erzhuang film and TV plays in China is much mature, but there is still no international film to the world. This requires not only the effect of "making big investment, big stars, big scenes, also need to complete the transformation of narrative strategies".

\subsubsection{The narrative of civilian heroes}

In the new period, in the film creation of war themes, most of them tend to shape the positive characters of the Chinese nation. Instead of selecting the heroes of "high, big and full" , "wei, guang, zheng" , they choose some civilian to inject fresh characters into them with heroism and humanism. On these little people, the audience can often find their own shadow and get a kind of spiritual comfort while watching the film.

The anti-war film in Tai'erzhuang can choose small figures as a narrative clue, and also to some extent avoid the repetition of many Tai'erzhuang films. For example, the aesthetic characteristics of civilians in the TV drama "the Past of Tai'erzhuang", the family feelings of the ordinary people, portrayed the small figures as the great heroes and created the narrative strategy of the heroic mythology.

\subsubsection{The perspective of the World War}

We need to stand at the view of World War to interpret the battle' s significance. Linking the eastern battlefields and the European battlefields together as a whole, to highlight that the anti-Japanese war is an integral part of the world anti-Fascist war.

As part of the World War II, the Chinese anti-Japanese war is the earliest and longest one. It promoted the historical process of World War II and made a great contribution to World War II too.

\subsubsection{Forgiveness and Reflection on the moral level of human nature}

What the war brought to us should not only the accusation of the Japanese, the revelation of the serious disasters; we should also think deeply about the devastation and scourge that the war brought to both sides of the war. In Tarkovsky film director "Ivan' s Childhood" , the director is keenly aware of the ravages of war brought to mankind, especially in children. Through Ivan, the director showed how the normally naïve children walked into the abyss of war step by step, and finally was brutally murdered. This point can be a good reference for Tai'erzhuang film. The return of humanism may bring new innovations and breakthroughs for the creation of film, and become a new historical work.

At present, China war movies still remain in the subject of national and state, but less attention is paid to the inner feelings of the individual in the war and the lack of deep human nature. If we want to present a good film on the theme of Tai'erzhuang, we still have a long way to go, whether from the introspection of war or the excavation of human psychology.

\footnotetext{
${ }^{1}<$ FAN Changjiang and the Battle of Tai'erzhuang >
} 


\section{Conclusions}

There are many film and TV boutique about the battle of Tai'erzhuang since 1930s; these films make people never forget the hardship of war and the shame of China. But it is also an urgent to adopt the international narrative strategy and let more people know the contrition of China in World War II, meanwhile to spread the Chinese national spirit and national image.

\section{References}

[1] ZHANG Guofan, Historical authenticity and film beauty-on the film "the Bloody Battle of Tai'erzhuang", Social Sciences of Guangxi, vol.4, 1988.

[2] YANG Guangyuan and ZHAI Junjie, A new theme, a new field, a new attempt-the director of "The Bloody Battle of Tai'erzhuang", Film Art, vol.8, 1987.

[3] YUAN Chengliang, The shoot of the movie "The Bloody Battle of Tai'erzhuang", General Review of the Communist Party of China, vol.3, 2009.

[4] GAO Ming, Objectively evaluates the historical position of the Tai'erzhuang campaign, Jiang Hai Academic Journal, vol.2,1994.

[5] LIN Ji'an, Rewriting and Reflection on the history of the war of resistance under the view of human nature-on the film on the theme of continental Anti-Japanese war in the new period(1979-1989), Peking, Communication University of China, 2013. 